\title{
ON THE WITHDRAWAL OF THE ROMAN TROOPS FROM THE DODECASCHOENOS IN AD 298: MANY QUESTIONS AND FEW ANSWERS - THE PROBLEMS IN PERSPECTIVE
}

\author{
B Hendrickx (University of Johannesburg)
}

In 298 Diocletian withdrew the Roman troops from the Dodecaschoenos, thereby - according to Procopius - making a treaty with the Nobadai and the Blemmyes and creating a buffer zone to be filled and administered by the Nubians. In this article I examine with which people(s) or groups the Romans fought at the Nubian limiton at the end of the $3^{\text {rd }}$ century AD and made peace, which was the former and later status of this 'buffer zone', and finally when and why was the balance, realized in AD 298, disturbed. There remain more questions than answers to the problems. This article discusses the different viewpoints and theories concerning the Roman withdrawal in the framework of the Meroitic Kingdom and the existing relationship with different tribes. This will lead to a more 'refined' understanding and assessment of the problematic of this historically complicated situation, and thus narrowing the problems, while proposing some solutions for some specific questions.

\section{Introduction}

In AD 298 Diocletian withdrew the Roman troops from the Dodecaschoenos according to Procopius (De bellis 1.19.27-37) making a treaty with the Nobadai and the Blemmyes. ${ }^{1}$ His testimonium can be supplemented by that of Olympiadoros (AD 423) and a number of inscriptions and graffiti, most of them to be found in the Fontes (1998). The theme has attracted much attention and produced a variety of proposed and supposed solutions.

Procopius gives the following reasons for the withdrawal of the Romans from the Dodecaschoenus: (a) the arable land was extremely narrow, there were rocks everywhere and the tribute coming from the region was not valuable, (b) the

The Blemmyes are considered to belong to the Beja tribe or are synonymous with the latter. See Kirwan 1957:15; Papadopoullos 1966:19: this author not only identifies the Beja with the Blemmyes, but put forward the hypothesis "that "Blemmyes" is a generic name applying to the native tribes of the Nubian desert east and west of the Nile, bordering on the limits of the civilized world and inevitably having contact with the Egyptian provinces in the north and the Ethiopian ethnic groups in the south'; Paul 1954:1-2,55 also believes that the Blemmyes were the Beja or perhaps a "more advanced' group of them. 
maintenance of Roman garrisons was very expensive, and (c) the Nobadai were plundering all places in the region. Therefore, the emperor persuaded the Nobadai to migrate and settle on both sides of the Nile, in the hope that they would drive out the Blemmyes from there. Then Diocletian decreed to pay every year an amount of gold to both the Blemmyes and Nobadai so that they would stop plundering Roman-Egyptian territory. However, both groups continued their incursions although they received their subsidy every year, even up to Procopius's time.

The Dodecaschoenos was a region between Egypt and Nubia (also named

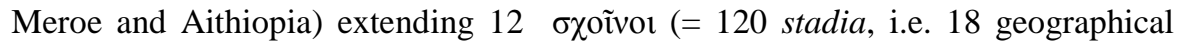
miles [Ptol. 4.5.74; Hdt. 2.29]). The northern frontier was at Philae, and the southern one at Pscelcis (Dakka) or — in the late Roman period — at HieraSycaminos. In the Roman times the Dodecaschoenos was attached to Roman Egypt and was viewed as a buffer state between the Roman Empire and the Meroitic Kingdom after the victory of Cornelius Gallus leading to the latter's trilingual inscription at Philae in 29 BC (OGIS II, no. 654, pp. 360-65; Hendrickx 1991:5561; Hoffmann, Minas-Nerpal \& Pfeiffer 2009) and the so-called treaty of Samos in 21 BC (Strabo XVII, 54).

Procopius's presentation of events has in general been followed by the older generation of modern scholars. Thus historians, writing on the Roman Empire in general and even specialists on the Egyptian limes (or $\lambda$ í directly or indirectly Procopius's viewpoint, such as, among many others, Milne (1924:80), Enßlin (1943:31,55), Jones (1964:611), Boak \& Sinnigen (1965:427), Papadopoullos (1966:8), Adams (1977:389), Barnes (1981:17-18), Bowman (1986:45) and Vantini (1981:24-26).

\section{An overview and analysis of the scholarly theories and interpretations}

2.1 L P Kirwan is arguably the scholar who has contributed most - during the second and third quarters of the $20^{\text {th }}$ century — to the study of RomanNubian history. While east of the Nile, the Beja (Blemmyes) were roaming in the deserts, west of this river numerous tribes, known in Antiquity as 'Ethiopians' or 'Nubians', 'whose wanderings and groupings are hard to disentangle' were present or on the move (Kirwan, 1957:15). A 'great migration of peoples called Noba' in the south-west, now known as Kordofan, took place in eastward and northward directions; together with the invasion of the Axumites ${ }^{2}$ this led to the final fall of Meroe by the middle of the $4^{\text {th }}$ century. On the other hand, the attacks of the Blemmyes-

For the controversy and interpretation of these texts, see - except the studies of Kirwan, Burstein, Lenoble \& Sharif, and Welsby, which are discussed in this article: Hägg 1984:36-441, Hendrickx 1997:90-95, Fontes, nos. 285, 286, 298 and 299. 
Beja on Egypt led to Diocletian's withdrawal (Kirwan 1957:15). The pax romana along the Nile River continued until the $4^{\text {th }}$ century and Meroe had been a Roman entrepôt for Roman trade with Central Africa, but the Noba invasions and then the Axumite attack led to economic decline of Meroe, which had become an easy target for invasions (Kirwan 1972:458, 460-464). Kirwan has also accepted Procopius's argument that the impoverishment of Meroe was one of the reasons for Rome's withdrawal from the Dodecaschoenos and this withdrawal may have encouraged the Axumite attack on Meroe, while the northwards-moving Noba then became known as 'Nobades' (Kirwan 1963:263, 270-271; 1957b:37-41 and 1958:69-73). When commenting on the so-called X people, known for their tombs in the latest stage of Meroitic civilization, Kirwan (1937:60) considered the $\mathrm{X}$ group as well as the Nobadai a negroid people. ${ }^{3}$ As for the Nubian language and its use, Kirwan (1937:60-61) notes two possible scenarios: either the Nubian language was introduced from the South Kardofan region by the 'Nubae' in the $3^{\text {rd }}$ century BC and co-existed as a spoken language next to the written Meroitic one, or it was introduced by the Noba in the $4^{\text {th }}$ century AD.

2.2 The renowned archaeologist W Y Adams (1983:93-103) has stressed that not only the Dodecaschoenos once belonged to the Roman Empire, but that there was also a Roman presence in the Triacontaschoenos, the region extending to the $2^{\text {nd }}$ cataract, which is known as Lower Nubia. Adams considered the suggested pre-Roman existence of an Egyptian-Kushite ${ }^{4}$ condominium as unacceptable to the Roman conquerors of Egypt. In $23 \mathrm{BC}$ the Kushites attacked the Roman frontier garrisons (at Philae, Syene, Elephantine), an action that ended with Roman reprisals and the 'treaty of Samos', which inter alia appears to have re-established a condominium (see also Desanges 1969:139-147). Adams accepts Procopius's assertion of Diocletian's withdrawal, which put the frontier at Philae. Nevertheless, Adams refers to a $3^{\text {rd }}$ century papyrus, indicative of the presence of a Roman legion at Primis (Qasr Ibrim, Phrim), south of Hiera Sycaminos (Adams 1983:94, 97; cf. Desanges 1969:145). The content of this

3 Adams 1993:19, in an unusual article, reviewing — rather superficially — the origin and role of the 'Nubians', remarks that they 'are the first historically recognizable black African people', and therefore Nubia was used in modern 'Afrocentric' research as the 'Mother of the World'. This Nubia, he remarks, is 'the black nationalists' Nubia'.

4 Kushite (or Cushite: the spelling varies from author to author) is used in modern scholarship as synonymous with Meroitic in the Nubian context. In this article I respected - as far as possible — the spelling followed by each author. 
document, which has not been compiled in the Fontes, has been confirmed by Olympiadorus, writing in 423 , who after having visited Primis states that this stronghold had once been Roman Egypt's most southern limes, although in Olympiadorus's time it was occupied by the Blemmyes. Adams further observes that the excavation at Qasr Ibrim confirms the presence of Roman soldiers, and that although the fortress was re-occupied by the Meroites after AD 100, it appears that there was still or again a Roman military centre as 'a military outpost on alien soil'. Adams explains this situation as follows: 'Nubians' immigrated into Lower Nubia from the Southern lands of the Empire of Kush (i.e. Meroe). The Dodecaschoenos was inhabited mainly by Egyptians and Romans, therefore the immigrants took the vacant lands nearby Primis, which at that time was mentioned in Meroitic inscriptions as Pederne. Thus, Adams concludes, one should distinguish between 3 limites, an administrative one (at Hiera Sycaminos), a military one (at Primis), and later on an ethnic one (again at Hiera Sycaminos). Adams explains this 'seeming anomaly' as follows: since there has been little or no Kushite settlement north of the $3^{\text {rd }}$ cataract since the last millennium BC, the Kushite power centre had shifted from Napata to Meroe. The real threat for the Romans in Lower Nubia and the limes zone were the Beja (Blemmyes). The fortress of Qasr Ibrim (Primis) was therefore maintained to prevent the Blemmyes from settling in the surrounding region, while on the contrary the settlement of the 'Nubians' was encouraged. This explains, according to Adams (1983:100; $c f$. Adams 1976:14-24), why 'Procopius has recorded how Diocletian invited the oasis-dwelling Nobatae tribe to occupy Lower Nubia, as a buffer against Blemmye attacks, at the time when he withdraw the Roman garrisons', and he stresses his conviction that the Nobadai were indeed the 'Nubian resettlers of whom we find so much archaeological evidence', thereby remarking that their immigration into Lower Nubia in reality began long before the period of Diocletian and the withdrawal of the Roman troops.

2.3 P Lenoble \& Nigm ed Din Mohammed Sharif (1992:626-35) have doubted that the collapse of Meroe was the result of an invasion of barbarians comparable to the collapse of the Western Roman Empire. On the contrary Meroe's collapse took its own course and the 'End of Meroe' ... would not designate a political or military event attributable to invasion or barbaric influence, but would describe a continuous evolution over the $4^{\text {th }}$ and $5^{\text {th }}$ centuries, leading the same Nilotic peoples from one political system to another' and thus from paganism to the three traditional Nubian Christian Kingdoms (Lenoble \& Nigm ed Din Mohammed Sharif 
1992:629). The two authors consequently appear to cast doubt on Procopius's mention of Nobadai ${ }^{5}$ (and not of Meroites), presuming that the Meroites and Nobadai were in fact the same people.

2.4 In 1998 Stanley Burstein (1998:125-132) presented a new interpretation, rejecting Procopius and the scholars who followed him, because (a) they ignored the role of the kingdom of Meroe, (b) because the Nobadai only occupied the Dodecaschoenos in the $5^{\text {th }}$ century $\mathrm{AD}$, and (c) because Diocletian was not intimidated by the Blemmyes, but successfully warred against them. Thus, relying on earlier research by Török (1980:82-85; 1988a:28-29; 1988b:282-285), Burkhardt (1985:16-18) and Kormysheva (1989:305-315), Burstein believed that it was the kingdom of Meroe that was the main beneficiary of Diocletian's withdrawal (not the Blemmyes and certainly not the Nobadai), although he states that this interpretation offers only a partial explanation, since the scholars to whom he referred, i.e. Török, Burkhardt and Kormysheva, 'presuppose that the Roman military presence in the Dodecaschoenos had already ended, when Diocletian decided to make Aswan the southern frontier of Egypt in 298 AD'. Here, according to Burstein, Procopius's insistence that the Roman forts in the Dodecaschoenos were still in existence in AD 298 proves to be correct since this is confirmed by a Latin milestone inscription (CIL 3.14148; text repeated in Burstein 1998:130), set up originally along a road in Lower Nubia, constructed or repaired between 293 and 298 AD (Burstein 1998:130). Burstein suggests that while Meroitic influence increased, some Roman forts were still maintained in the Dodecaschoenos. This policy of Diocletian thus aimed at shifting the control over the Blemmyes to Meroe, a policy that 'enjoyed a considerable degree of success' (Burstein 1998:131).

2.5 In the same year as Burstein's publication, volume 3 of the excellent edition and commentary by T Eide, T Hägg, R Holton Pierce \& L Török on the textual sources of the Middle Nile Region from the $1^{\text {st }}$ to the $6^{\text {th }}$ century AD was published (Fontes 1998). It contributed to a new understanding of several Nubian documents of the Late-Roman and early medieval period as well as to the chronological order of events. It has also shed new light on the border situation around Philae in the time of Diocletian.

Modern authors have spelled the name of this tribe in different ways: Nobatai, Nobadai, Nobatae, Nobadae, Nobates and Nobades. In this articles we will adopt the spelling 'Nobadai', but we respect the authors' spelling when we quote their texts. 
L Török, commenting on the withdrawal of the Roman frontier in AD 298 as well as on Procopius (De Bellis 1.19.27-37), has stated that Procopius's information according to which the withdrawal of the Romans coincides with the 'settlement of the Nobatai in an evacuated Dodecaschoenos', cannot be accepted. He believes it more probable 'to assume that the vacuum [...] was filled by the Meroitic kingdom, which during the second and third thirds of the $3^{\text {rd }}$ century $\mathrm{AD}$ exerted an increasingly effective control over this territory, i.e. a territory which was inhabited mainly by a non-Egyptian, 'Aithiop-ian' (sic) population and that the re-settlement of the region as well as its new military organization therefore was no longer a Roman task, but became a Meroitic one' (Fontes 1192-3). Török thereby accepts the possibility of a Roman treaty — at the same period — with the Blemmyes (Beja), but not with the Nobadai.

2.6 D A Welsby, publishing his book on the Medieval Kingdoms of Nubia in 2002, does not agree with Burstein's scenario (of which he was not aware), neither with that expressed by Török in the Fontes. He notes that the Romans had two policies vis-à-vis the 'barbarians' on the Nubian limiton. Citing John of Ephesus, he points out that subsidy was paid to the Nobadai, and repeating Procopius he accepts that Diocletian persuaded the 'barbarian' Nobadai to migrate (Welsby 2002:18). He then uses the testimonium of Olympiadorus (of 423), an inscription of the Blemmyan phylarchos Phoinen in the Mandulis temple, dating from the beginning of the $5^{\text {th }}$ century (Wilcken 1901:413; cf. Fontes, no. 313), the triumphant inscription of King Silko, a Nobadian, dating from some years before 450 (OGIS I 201; cf. Fontes no. 317), the Coptic correspondence of the Roman commander of the Egyptian limiton troops with Tantani, phylarchos of the An(n)oubades (ca. 450) (Fontes, nos. 320, 321, 322) and finally the peace treaty of 452 (or 453?), inscribed in the temple of Philae (Prisci Panitae Fragmenta no. 21), as illustrations and proof that the Roman policy had — in contradiction to Burstein's belief — only limited success (Welsby 2002:18-19). Finally, Welsby believes that 'we have a plethora of names which may refer to a single people, among them Nubae, Nobades, Nobates, Annoubades, Nouba and Red Noba' (2002:15). Welsby accepts that Procopius's reference to the Nobadai may be an anachronism and that it was the Cushites (i.e. Meroites) who 'stepped into the vacuum left by the withdrawal of Roman garrisons, if such a vacuum ever existed' and that the Cushite State (i.e. the Meroitic Empire), which was entering its final phase by the end of the $3^{\text {rd }}$ century AD, most likely broke up along the Nile river in a number of parts (Welsby 2002:15-17; $c f$. also Welsby 2006). He also 
refers to the inscription of Kharamadoye (Fontes no. 300), who was an independent ruler ('qore' ruler) of Lower Nubia (early $5^{\text {th }}$ century), having successfully fought king Yismeniye (i.e. probably the Blemmyan King Isemne). Kharamadoye maintained his links, however, with the Meroitic culture by using the Meroitic language in his inscription, which was the last one written in that language. Welsby further assumes that the Nobadae 'were presumably the subjects of Kharamadoye' (Welsby 2002:16-17).

2.7 Two years after Welsby's book, D N Edwards published his own study on the Nubian past (Edwards 2004). He approaches the Late-Roman and Post-Meroitic periods mainly from an archeological point of view. He heavily criticizes the different constructions of $20^{\text {th }}$ century authors around the 'end of Meroe', considering them elaborate and imaginative, but leaving the fundamental problems unsolved. He believes that the Axumite texts are by no means straightforward, and that the Noba and Khasa, mentioned in these inscriptions cannot be identified with certainty, and doubts Burstein's belief that Meroe had become a vassal of Axum (Burstein 1981:47-50 [= Burstein 1995:207-211]). He also tends to reject the theories of Adams (1977:385) and Török (1987a:179), who suggested that Axumite competition in the trade with Late-Roman Egypt was a contributing factor to Meroe's decline, stating that 'modern perceptions of international trade and commercial competition which underlie such suggestions seem anachronistic' (Edwards 2004:183-184). Therefore, the disappearance of the Meroitic State 'must be sought in the political dissolution or devolution of that state' (Edwards 2004:185), while the migration theories of Noba and Nubian tribes were 'simple explanations' of the last century.

2.8 Finally, recently Effrosyni Zacharopoulou (2010:305-333) tackled the problem 'Procopius and Diocletian' in an interesting article, written in Greek, which claims to solve the problem. Her basic aim is to approach Procopius's account and the measures taken by Diocletian to secure the defense of the southern limes of Egypt critically, as well as to assess how justified Procopius was in referring to the Nobadai. She believes that the Dodecaschoenos was in the Roman period a poly-ethnic and multi-lingual society, consisting of Greeks, Romans, Egyptians and [often Hellenized] Blemmyes, but especially a society of a population that came from the south (i.e. Meroe) and whose people was known as 'Aithiopians'. The governance of the Dodecaschoenos is centered on the Isis-cult. She also holds that during the $3^{\text {rd }}$ century the Meroites profited from the crisis in the Roman Empire to promote via the Isis cult their own administrative 
organization over the Dodecaschoenos. Diocletian was in Egypt to terminate the revolt of Domitian, and went southwards, where he defeated the Blemmyes and the Meroites after which he recognized the de facto situation in the Dodecaschoenos, which he strengthened the Philae region with strong fortifications. She explains Diocletian's decisions by the stagnation of trade with and through the Dodecaschoenos and the importance of trade with Ethiopia through the port of Adoulis. Moreover, the Meroites would now be obliged to contain the Blemmyes and Nubian tribes which moved in Lower Nubia from the south (since the $3^{\text {rd }}$ century $\mathrm{BC}$ ?) and thus the people of Lower Nubia consisted greatly of Nubians, who became 'meroiticized', strongly connected with the Isis cult and its temples. From the $4^{\text {th }}$ century Christianity took over the Roman religious framework. Since the bulk of the 'Aithiopian' population of the Dodecaschoenos consisted of Nubians during the later part of the $4^{\text {th }}$ century, the Meroitic 'elite' was no longer able to control the Dodecaschoenos and new rulers (the so-called X group or Ballana, known by their tombs) took over. Thus there was a transition to replacement of the Meroitic culture by a Nubian one, in which Nubian became the new general and dominating language. This explains the origin of the kingdom of Nobadia and its wars with the Blemmyes. When Procopius referred to Nobadai, it was an anachronism as for the name, but still the population was greatly 'Nubian' in Diocletian's time.

3. Toward some conclusions and new solutions: A critical assessment of the theories

The disagreement and contradictions between historians from Procopius to Zacharopoulou mainly concern the following aspects, which are interconnected:

(i) Which people(s) the Romans fought at the Nubian limiton at the end of the $3^{\text {rd }}$ century $\mathrm{AD}$ and made peace with?

(ii) Which were the relations between the different groups on the limiton, i.e. Blemmyes, Nobadae, Romans, Aithiopians, and Meroites?

(iii) When and why was the balance reached in AD 298 disturbed? Was a new population displacement one of the causes? and

(iv) Should the problem of the Dodecaschoenos (and Triacontaschoenos) be put in a wider geographical context, i.e. this of the larger Meroitic region? 
3.1 The different theories, exposed supra, have not only very often contradicted each other, but also - to a point — refuted each other. By having examined and debated the same problems from different and new angles within their own specific chronological period of ideas and prejudices, they produced nevertheless a valuable deposit, which can be used and re-used to refine our historical insights within the framework of the intellectual milieu of the day.

3.2 The theory of invasions (by Noba, Nobadai, Axumites), promoted or accepted - to different degrees - by Kirwan, Burstein, Török, Welsby and even Adams has been strongly criticized, if not outright rejected by Lenoble and Sharif and recently by Edwards, who have denied the concept of a destruction of Meroe ('End of Meroe') as a result of invasions. Instead they believe that Meroe's decline should be explained by internal factors.

The initiators of this 'new' theory do not comment on the reasons for Diocletian's withdrawal and do not try to solve the causes and circumstances of the 'immigrations' (and not 'invasions') or debate the origin and ethnicity of tribes in the Meroitic Empire and more specifically in the Dodeca- or Triacontaschoenos, neither do they date these 'immigrations'. Edward's outright rejection of economic factors, specifically in the Roman-Meroitic-Axumite context, as contributing to Meroe's decline as anachronistic, does not hold water. In fact, commercial activities between Egypt and its southern neighbours date from ancient Egyptian times, while the 'economic decline theory' is not a $20^{\text {th }}$ century 'imagery', but is solidly based on financial grounds which have been explained by an ancient source (Procopius). These commercial factors could well be one of the determining 'internal' developments, which Edwards appears to favour as a cause, although there is no final evidence for this. The withdrawal of the Roman troops in AD 298 by Procopius is therefore certainly not a $20^{\text {th }}$ century 'imagery'. The weakening of the safety and security situation in the Dodecaschoenos and the mention of strong local rulers and leaders - as we shall see infra - may reflect the economic decline, which in turn may probably have been precipitated by civil and military unrest. Whether one accepts or nor that the Nobadai or other 'Nubians' had already started their marauding and incursions before the $4^{\text {th }}$ century, does in no way reason away or diminish the existence of the continuing threat by the Beja, of which the sources testify. ${ }^{6}$

One can assess the Beja activities from a larger number of documents (Fontes nos. 279, $280,282,283,284,293,295,296,302,305,308$ ) as well as from Ezana's inscriptions in Nubia. 
It is therefore most plausible that peaceful immigration by tribes such as the Noba and other 'Nubians' into Meroitic territory was alternated by brutal invasions, and that the integration process of these newcomers into Meroitic civilization and the 'Aithiopian' population as well as violent changes introduced by invaders contributed to the 'end of Meroe'. It is also quite impossible to cast doubt on the Axumite invasions, since Axumite inscriptions were found at Meroe itself. Whether the Meroitic kings became or did not become vassals of Axum is - for this article - not directly relevant, but these invasions certainly contributed to Meroe's final decline.

3.3 Whether Diocletian's withdrawal created a vacuum is relative and indeed debatable. The withdrawal, which probably was not absolute, does not appear to have created a 'new' situation, and since Diocletian and his successors paid subsidy to the Blemmyes and to the tribes then living in the Dodecaschoenos, who were later used as foederati or symmachoi (cf. Fontes nos. 309-313 and 320-322). ${ }^{7}$

The epigraphs gathered and commented in the Fontes by Holton Pierce and Török convincingly illustrate the presence and cultural-religious supremacy of the Meroites in Philae and even such places as Qasr Ibrim (cf. Fontes no 276) in the Dodecaschoenos (and Triacontaschoenos) from the middle of the $3^{\text {rd }}$ century AD to 298: there are no fewer than nine Meroitic demotic graffiti from Philae, referring to or mentioning Meroitic kings and princes (Fontes nos. 249, 250, 252, 256, 257, 259, 260, 261, 262 ) as well as four from Dakka (Fontes nos. 251 [with one hieroglyphic and one demotic graffito], 254, 255). Most of them are also connected with a proskynema to Isis. Moreover, at Karanog there is a Meroitic funerary non-royal inscription of the 'noble' high official, Netewitar, and a Greek proskymena inscription of Abratoye (Abratoeis) in Philae, who was the 'psentes ${ }^{8}$ of the King of Aithiopia' (Fontes, no. 265). There are also a demotic Meroitic and a Greek proskynema of Tami, who was a tax collector of Isis at Philae for the Roman Emperor and at the same time the

There is some confusion between the use of the terms foederati and symmachoi in the Northern African context. Maspero 1974:61-63 holds that the foederati in Byzantine (i.e. Late Roman) times, in Constantinople and Alexandria, were not organized according to tribal lines, like the classical ones. Troops like the old foederati were now known as symmachoi.

8 'Psentes' ( $\psi \varepsilon \dot{\varepsilon} v \tau \eta \varsigma)$ is the Greek version of the Meroitic term 'peseto', meaning 'son [of the king]', i.e. governor (Török in Fontes 1022). Such governors were appointed for a limited period. They should not be confused with the 'qore', who were independent (or semi-independent [?]) rulers or kings. 
tax collector for the estates under the control of the king of Meroe (Hägg and Török, in Fontes nos. 261, 266).

Moreover, in the Meroitic Chamber of the Isis temple in Philae, there are inscriptions of a Meroitic embassy, where names, referring to the queen, the peseto (i.e. the 'king's son = the governor [of Lower Nubia]) and high military and administrative Meroitic persons are mentioned $\left(2^{\text {nd }}\right.$ half of $3^{\text {rd }}$ century; Fontes no. 267). At Karanog again there is the funerary cursive Meroitic inscription of Khawitaror, peseto Akinte ('the King's son in Lower Nubia') (Fontes no. 268), and at the same place also a funerary Meroitic inscription of peseto Abratoye (Abratoeis) of the same period is found (Fontes no. 270).

Finally one should mention an inscription in Faras (Pachoras) referring to pesetos and higher military commanders (Fontes no. 271) and a demotic graffito of Teo, 'the Lord of the water' (i.e. probably the admiral of the Meroitic Nile fleet) from AD 273. The latter graffito is interesting since it is dated to the 'fourth regnal year of Aurelian', thus recognizing the Roman importance in the region (Fontes no. 272).

Modern scholars have in general ignored in their discussions a Latin graffito from the $3^{\text {rd }}$ or $4^{\text {th }}$ century at the Great Enclosure at Musawwarat es Sufra (CIL III,83; cf. Fontes no. 297):

Bona fortuna. Dominae

Reginae in multos an-

nos feliciter! venit

e urbe mense Apr.

die $X V$ traces

-tus

[Good fortune! To (Our) Lady the Queen with wishes for success for many years to come (...)tus arrived from the city on the $15^{\text {th }}$ day of the month of April.] (translation by Eide, in Fontes p. 1093).

While Hintze (1964:298) has suggested that the regina is a queen of Meroe, Török (1886a:357 and Fontes:1094) believes that it refers to the goddess Isis. He also believes that the text was written by some foreign visitor, anyway someone who spoke and wrote Latin and that Latin was the official language of the Roman army. However, I do not see why a 'Latin speaking visitor' would visit a monument in Musawwarat es Sufra and refer to the Meroitic queen or Isis. Such a person, who certainly was not an 'Aithiopian', Egyptian or Greek, since he would not be Latin speaking and would not 'erect' a Latin dedication in Nubia, should be — in my view — 
an official Roman visitor, i.e. an envoy or a military. Indeed, if the graffito dates from the $4^{\text {th }}$ rather than the $3^{\text {rd }}$ century as suggested by Török (in Fontes 1093), one should wonder what at this late stage such a personage was doing in Nubia if not representing the Roman government or army. Such an eventuality would be an argument in favour of prolonged Roman involvement in Lower Nubia, be it political or military. Combined with the earlier Latin milestone inscription (CIL 3.14148 ${ }^{3}$ ) from between AD 293 and 298 (Burstein 1998:130), which has been ignored by the authors of the Fontes and Welsby, this graffito may give reason to presume that the withdrawal of Diocletian was not so final and definitive as stated by Procopius, and might even explain Welsby's doubt about the existence of a vacuum created by the evacuation ordered by Diocletian (Welsby 2002:15).

3.4 The mention of a 'Nuba' in an inscription at Philae dates to ca. 537 (Fontes no. 325) and is written in Greek. The fact that someone identifies himself with the old identity of 'Nuba', as opposed to the term Annoubades or Noubadai, indicates that people created a new identity or were seeking for one. The last inscription in demotic Meroitic dates to the late $4^{\text {th }}-$ beginning $5^{\text {th }}$ century (inscription of qore [king, ruler] Kharamadoye: Fontes no. 300), and the last inscription in hieroglyphic as well as demotic Meroitic dates to 394 (graffito of Esmêtakhon: Fontes no. 306). There are a number of Greek inscriptions and other written sources during the $3^{\text {rd }}$ century relating to Blemmyes-Beja (Fontes nos. 279, 280, 281, 282, 283, 284). All these inscriptions show that from the $3^{\text {rd }}$ to the $5^{\text {th }}$ century the population of Lower Nubia went through a transformation, which was political as well as cultural and linguistic.

3.5 One can say with some degree of certainty that Diocletian's withdrawal made space for the last 'Aithiopians' of the disintegrating Kingdom of Meroe and not for the Nobadai as an independent group. These 'Aithiopians' thus appear to be the descendants or remnants of the original population of the Ancient Dodecaschoenos, but it is impossible to say whether they were already a mixed population or not. Nomenclature does not help us a lot. The term 'Nuba' stems from Antiquity and was still used in Meroitic texts of the period of Diocletian, while the ancient Greeks refer to 'Noubai' and the ancient Egyptians used 'Nuba', linking it with their word $n u b$ for gold (cf. Kirwan 1937:47-48; Vantini 1981:24-25; Zacharopoulou 2010:313-314) In the beginning of the $4^{\text {th }}$ century, the Axumite king Ezana who conquered Meroe or a part of it, speaks about the 
'Red Noba' and the 'Black Noba'. ${ }^{9}$ Only in the first half of the $5^{\text {th }}$ century do we encounter the terms 'Nobadae', 'Nobatae' and 'An(n)oubades' or 'nation of the Anouba' in the sources. Modern authors have not helped the confusion, because they very often use the terms as synonyms for each other, which — sensu stricto - they are not. Vantini (1981:26), trying to conciliate different theories, proposed that the "Noubai moved northwards from Kordofan, came into the Nile valley and mixed with the local population who had been there since Meroitic times'. Another people, the Nobadai came from the western desert, won control and 'intermingled with the Noubai, forgot their own language and began to speak that of the majority'. Although Vantini sees in these movements a logical explanation for the fact that there are resemblances between the language of the 'Nobiyin' (the present day Nubians) and today's languages of the Nuba Mountains as well as those of some Berbers in North Africa, his explanation has not been accepted, since there are basic flaws. The original inhabitants of the Dodecaschoenos belonged to the Meroitic Empire, and the inscriptions use the Meroitic language (hieroglyphic and demotic), which up till now is only partly understood. Their language was certainly not the later Nubian (Nobadian and / or Makourian) language, which survived today in some parts of Sudan in a modern form. As 'Meroites' they were the old 'Aithiopians' (of the Greek sources), also called 'Noubai' by the ancient Greeks and 'Nuba' by the Meroites themselves. ${ }^{10}$

3.6 It is indicative that the Nobadian ruler, Silko, in his triumphal inscription at Kalabsha (some time before $450 \mathrm{AD}$ ) uses the title of ' $\beta \alpha \sigma i \lambda$ í $\sigma$ к

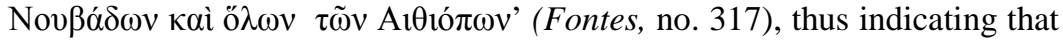
even at that later stage Lower Nubia was inhabited by Nobadai as well as 'Aithiopians', the latter being the descendants or the survivors of the original Meroitic (or Cushitic) population. The term 'Aithiopians' certainly

9 Paul 1954:46 believes that the black Noba were a dark-skinned tribe from the South, who had occupied - Ezana's time - a great part of the Meroitic kingdom, while the Red Noba, also mentioned by Ezana, were living more northwards. Paul also believes that it is 'quite possible' that these are the ones that Diocletian had subsidised in 298.

It is remarkable that the editors of the Fontes appear to avoid the issue. Thus, in their vol. 4 (Corrigenda and Indices, Bergen, 2000:1307- 08) they list Noba/N(o)uba(i), Nobatai, Noubades / Noubadians, Nuba, Nubai and Nubians (Nhsyw), thereby referring Nobatai to Noubades/Noubadians, Nuba and Nubai to Noba and considering Nubians (Nhsyw) as an entry apart, thus reducing all the forms to 3 basic ones : Noba/N(o)uba(i), Noubades / Noubadians and Nubians (Nhsyw). However, the texts, to which the index refers, give no clear idea about the differences of the terms or the 'ethnicity' of the groups. 
does not refer the Blemmyes, who were the foes of Silko (Hendrickx 1984: no.16; Fontes no. 317). ${ }^{11}$

3.7 Török's opinion that Diocletian gave the Dodecaschoenos to the Meroites is - as a result of the inscriptions and pending the definition of the term 'Meroites' — correct, but that does not 'identify' the 'Aithiopians' in this region purely as Meroites, in exactly the same manner as (later) inscriptions in Greek and Coptic made these inhabitants neither Greeks nor Copts. It also is very doubtful that the task of keeping out the Blemmyes and safeguard the Roman limes was since AD 298 shifted to the Meroitic Kingdom itself, which was declining, since the so-called vacuum was filled by independent rulers with a Meroitic culture and probably still recognizing in theory the overlordship of the King in Meroe until when, at a later stage ${ }^{12}$, these rulers were succeeded by rulers coming from the Nobadai tribe.

Moreover, Török (in Fontes 1141) does not seem to be very convinced about the relations or differences between the old 'Nuba' and the later An(n)oubades (Nobadai). At the occasion of his commentary on the petition of Bishop Appion in the Thebaid to Emperors Theodosius II and Valentinian III (Feissel-Worp 1988:97-111; Fontes no. 314), who complains about barbarian attacks, more specifically of Blemmyes and An(n)oubades, Török rather confusingly considers the An(n)oubades as 'representatives of the large family of Nubian-speakers appearing in the ancient sources as Nuba'. In fact, the An(n)oubades should be identified as Noubadai as can be inferred from the sequence of documents and events from Tantani to Silko ( $c f$. Fontes nos 317-322).

The fact that parts of Török's explanation are correct, does not entail necessarily the incorrectness of Procopius's information. In a discussion of Diocletian's withdrawal by Paul (1954:57), we read that the Nuba relations with the Beja were uncertain. Moreover, Paul appears to understand that Procopius 's reference to 'Nobadae' is in fact nothing else than a reference to the 'Nuba'. Zacharopoulou's conclusion (2010:325-

11 The Greek contemporary sources never call the Blemmyes 'Aithiopians'. Interestingly, Papadopoullos 1966:15-16 believes that the Nobadae were not a unified people, but were 'constituted by a number of tribes', Silko being the headman of one tribe, 'imposing his rule on related tribes'. He rather convincingly refers to lines 17-18 of

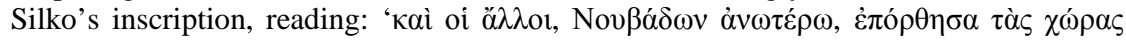
$\alpha$ ¿ $\tau \tilde{\omega} v$ '. His conclusion, which is nothing more than an assumption, is that therefore Silko's kingdom comprised Meroe and stretched as far as the Ethiopian territory.

12 It is quite impossible to give an exact date for this event, which probably was not a violent one. 
326) is similar. This may indeed be the correct approach for understanding Procopius's information. In the same way as modern authors continue to confuse the different 'Nubian' peoples (Nubians, Nuba, Nobadai, Noba, etc.), Procopius - writing his work in Constantinople during the $6^{\text {th }}$ century - was in no position to grasp the difference between these nominations, and used the term 'Nobadai' (which was a current term in his century) for the non-Beja inhabitants of Nubia, thus not referring to any particular 'tribe' or 'group' of Nubians. As such, his analysis of the facts is correct: Diocletian made peace with the 'Nubians' in the Dodecaschoenos and also with the Beja, who did not belong to the old Meroitic Empire.

3.8 As for the Beja, it has been proposed that they formed a sort of confederated kingdom and that only the king of the confederation used the title of basileus, while chiefs of subtribes or smaller groups would be basiliskoi and / or phylarchoi. Even a cursus honoris has been proposed, based on such titles. ${ }^{13}$ However, one should doubt the existence of a 'confederated kingdom' at all times or even pose the question whether there might have been more than one 'confederated kingdom' at the same time. To avoid the problem, some authors speak of 'marauders' or 'dissidents' to indicate groups, who did not include all the Beja, and of marauding Annoubades, who were in temporary alliance with the Beja (cf. Török in Fontes 1141). It therefore is far from certain — in my opinion — that Diocletian made peace with a 'confederated Beja king' in 298. ${ }^{14}$

13 It is true that the small Beja groups subjugated in the beginning of the $4^{\text {rd }}$ century by the Axumite king Ezana are called basiliskoi, and also the later Beja kings (or kinglets) of the Gebelein documents (Fontes nos. 334, 336; Hendrickx 1996:152-164) call themselves basiliskoi. But so does Silko! Moreover, the basiliskoi of the Gebelein documents appear in a Greek-Coptic text of the same group as ПРPO, which is the currant Coptic term for 'King'. (Fontes no. 339). It is therefore accepted that basileus and basiliskos were in fact used in Nubia as synonyms. It is thereby important to note that both basileis (e.g. Phonen) and the later basiliskoi of the Gebelein documents were assisted by phylarchoi and hypotyrannoi.

14 Török (in Fontes 1057), while commenting on the war between Meroe and the BejaBlemmyes in 291, writes that the Blemmyes of the region between the Red Sea and Lower Nubia appeared at that time to be moving towards a 'united tribal kingdom'. Paul 1954:59 categorically rejects the opinion that the Beja had 'any organized form of government', but that each group had his own chief. However he admits that they were 'ready as ever to unite under an outstanding leader for a major raid against their neighbours' and that they later appear to have united to form a petty kingship, and that they 'had some pretensions to a settled existence and an orderly form of government' some time before Olympiadorus's visit to Syene in AD 423. 
3.9 As for the condominium of Romans and 'Aithiopians' (Meroites), it appears that this situation, whether de jure or de facto, was on and off from the Gallus episode onwards until at least the withdrawal of Diocletian's troops, interrupted by wars and then re-established by peace agreements. The success of Diocletian's withdrawal can be assessed in different terms: financially, it appears that the Roman subsidy had only a limited success, while militarily the so-called 'one hundred year' peace imposed on the defeated Beja and Nobadai by the Roman-Byzantine commander Maximinus in AD 453 and its very brief duration cast much doubt on the long-term success of the Roman withdrawal. The usefulness of Beja and Nobadai used as auxiliary troops even at a later stage (foederati or symmachoi) remains debatable. ${ }^{15}$

\section{Conclusion}

The overview, analysis and critical assessment of the theories and 'solutions' for the problems regarding Diocletian's peace with the 'Nubians' in AD 298 have clearly illustrated their shortcomings and the remaining problems. It would be foolish to pretend that I solved all these problems, but not only are these now clearly identified and defined, but for several remaining questions, posed under section 3, solutions have been presented. Thus, it can be accepted as fact that while by the end of the $3^{\text {rd }}$ century $\mathrm{AD}$ the Romans were — at least partially withdrawing their troops from the Dodecaschoenos, the vacuum was filled by different groups, including immigrating tribes, who slowly integrated with the original 'Ethiopians' of the region. This led to an autonomous Meroitic 'principality' in the region, where Meroitic remained for some time the official language of the leaders and Nubian the 'new' people's language. Eventually a new identity of 'Nobadai' was formed and a Nobadian Kingdom created. The Romans also made peace with the Beja in AD 298, because without such a peace the withdrawal from the Dodecaschoenos would lead to a military and political catastrophe. ${ }^{16}$

15 See e.g. the content of the alleged letter of Byzantine Emperor Justin to the Ethiopian Axumite ruler, Kaleb, in which he mentions sending Blemmyan and Nobadian troops to Kaleb in order to attack the land of the Homerites (Yemen), where the Christians were persecuted: $c f$. Hendrickx 1984:66-69, no. 14. Another later example is the controversy around the Blemmyan troops, supporting the Byzantines against the invading Muslims from Egypt: Hendrickx 2012:110-11; El-Tahir 1994:97-123; idem, 2007:153-156.

16 This peace held for a short time only, and Beja infiltration or even rule appears to have continued until Silko's conquests, but this falls outside the scope of this article.

I wish to thank the NRF for supporting my research programme. 


\section{BIBLIOGRAPHY}

\section{ABBREVIATIONS}

$C I L=$ Corpus Inscriptionum Latinarum I-IV. Berlin, 1828-1877.

Fontes = Eide, T, Hägg, T, Holton Pierce, R \& Török, L (eds.), Fontes Historiae

Nubiorum: Textual sources for the history of the middle Nile region between the eight century $B C$ and the sixth century AD, Vol. III, From the first to the sixth century AD. Bergen, 1998.

OGIS = Dittenberger, W. Orientis Graeci Inscriptiones Selectae I-II, Leipzig, 1903, 1905.

Olympiadorus = Müller, C (ed.), Fragmenta Historicorum Graecorum. Paris, Vol. 3, 1849.

Prisci Panitae Fragmenta = Müller, C (ed.), Fragmenta Historicorum Graecorum. Paris, IV, no. 21, pp. 100-101.

Procopius, De Bellis = Procopii Caesariensis Opera Omnia, ed. J Haury-Wirth. Vol. I De Bellis libri I-IV. Leipzig, 1962.

\section{SOURCES}

Adams, W Y 1977. Nubia: Corridor to Africa. Princeton: Princeton University Press.

Adams, W Y 1976. Meroitic North and South. Meroitica 2:14-24.

Adams, W Y 1993. The invention of Nubia. In Hommages à Jean Leclant, BdE 106/2:17-22.

Adams, W Y 1983. Primis and the 'Aethiopian' Frontier. Journal of the American Research Center in Egypt 20.93:1-4.

Barnes, T D 1981. Constantine and Eusebius. Cambridge: Harvard University Press.

Boak, A E R \& Sinnigen W G 1965: A history of Rome to AD 565 (5 $5^{\text {th }}$ ed.). New York \& London: Macmillan.

Bowman, A K 1986: Egypt after the Pharaohs 332 BC-AD 642. Berkeley \& Los Angeles: University of California Press.

Bowman, A K 1978. The military occupation of Upper Egypt in the reign of Diocletian. BASP 15:25-38.

Burkhardt, A 1985. Ägypter und Meroiten im Dodekaschoinos. Meroitica 8. Berlin.

Burstein, S 1981. Axum and the fall of Meroe. Journal of the American Research Center in Egypt 18:47-50.

Burstein, S 1995. Graeco-Africana. New Rochelle: Caradzas. 
Burstein, S 1998. The Roman withdrawal from Nubia: A new interpretation. Symbolae Osloenses 73.1:125-132.

Desanges, J 1969. Le statut et les limites de la Nubie romaine. CdÉ 44:139-147.

Edwards, D N 2004. The Nubian past: An archaeology of the Sudan. London \& New York: Routledge.

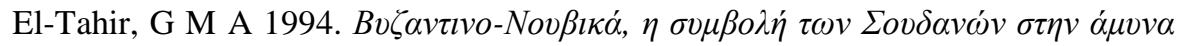

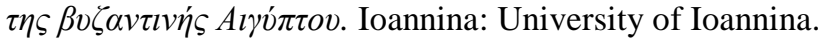

El-Tahir, G M A 2007. Main geographic terms of Upper Egypt in the Arabic romance epic Futuh al-Bahnasa: A preliminary report. In Yousef al-Hijji, Y \& Christides, V. Cultural relations between Byzantium and the Arabs, 153156. Athens: Institute for Graeco-Oriental and African Studies.

Enßlin, W 1943. Zur Ostpolitik des Kaisers Diokletian. Sitzungsberichte der Bayerischen Akademie der Wissenschaften, Phil.-Hist. Abt. Munich: Beck.

Feissel, D \& Worp, K A 1988. La requête d'Appion, évêque de Syène, à Théodose II. Oudheidkundige Mededelingen 68:97-111.

Hägg, T 1984. New Axumite inscription in Greek from Meroe: A preliminary report. Meroitica 7:436-441.

Hendrickx, B 1984. Official documents written in Greek illustrating the ancient history of Nubia and Ethiopia. Johannesburg (Monumenta AfroHellenica I).

Hendrickx, B 1991. Die drietalige inskripsie van Gallus (29 v.C.) te Philae as casus belli. Akroterion 36.1/2:55-61.

Hendrickx, B 1996. A propos de trois chartes grecques (blémyes) de Gebeleïn. Ekklesiastikos Pharos 78 (New Series 7):152-164.

Hendrickx, B 1997. A propos des inscriptions axoumites de Meroe. Acta Classica 40:90-95.

Hendrickx, B 2012. The border troops of the Roman-Byzantine southern Egyptian Limes: Problems and remarks on the role of the African and 'Black' African military units. Ekklesiastikos Pharos 93 (New Series 23):95-114.

Hoffmann F, Minas-Nerpal, M \& Pfeiffer, S 2009. Die dreisprachische Stele des C Cornelius Gallus. Berlin: De Gruyter.

Jones, A H M 1964. The later Roman Empire 284-602: A social economic and administrative survey. Oxford: Blackwell.

Kirwan, L P 1957a. Rome beyond the southern Egyptian frontier. The Geographical Journal 123.1:13-19.

Kirwan, L P 1957b. Tanqasi and the Noba. Kush 5:37-41.

Kirwan, L P 1958. Comments on the origins and history of the Nobatae of Procopius. Kush 6:69-73.

Kirwan, L P 1959. The international position of Sudan in Roman and Medieval Times. Sudan Notes and Records 40:23-37. 
Kirwan, L P 1963. Land of Abu Simbel. The Geographical Journal 129.3:261-273. Kirwan, L P 1972. An Ethiopian-Sudanese frontier zone in ancient history. The Geographical Journal 138.4:457-465.

Kirwan, L P 1937. A survey of Nubian origins. Sudan Notes and Records 20:47-62.

Kormysheva, E Y 1989. Political relations between the Roman Empire and Meroe, 305-315. Studia Meroitica 1984 (Meroitica 10), Berlin.

Lenoble, P \& Nigm ed Din Mohamed Sharif, 1992. Barbarians at the gate? Antiquity Journal 66.252:626-635.

Maspero, J 1974. L'organisation militaire de l'Egypte byzantine. Hildesheim New York, 1974 (reprint).

Milne, J G 1924. A history of Egypt under Roman rule. $3^{\text {rd }}$ ed. London: Methuen.

Papadopoullos, T 1966. Africanobyzantina. Byzantine influence on NegroSudanese cultures. Athens: Academy of Athens.

Paul, A 1954. A history of the Beja tribes of the Sudan. Cambridge: Cambridge University Press.

Shinnie, P L 1955. The fall of Meroe. Kush 3:82-85.

Török, L 1980. To the history of the Dodekaschoenos between ca. $250 \mathrm{BC}$ and 298 AD. ZÄS 107:76-86.

Török, L 1988a. Late antique Nubia: History and archaeology of the southern neighbour of Egypt in the $4^{\text {th }}-6^{\text {th }}$ c. A.D. Budapest: Archaeological Institute of The Hungarian Academy of Sciences.

Török, L 1988b. Geschichte Meroes: Ein Beitrag über die Quellenlage und den Forschungsstand. ANRW 2.10.1:107-341.

Vantini, G 1981. Christianity in the Sudan. Bologna: EMI.

Welsby, D A 2002. The Medieval kingdoms of Nubia. London: British Museum Press.

Welsby, D A 2006. Settlement in Nubia in the Medieval Period. Acta Nubica, proceedings of the Nubian Society conference, I Caneva and A Roccati (eds.). Rome: Libreria Dello Stato.

Wilcken, U 1901. Heidnisches und christliches aus Ägypten. Archiv für Papyrusforschung: 396-436.

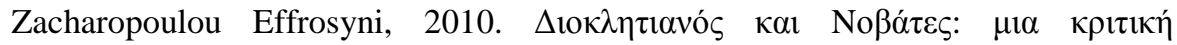

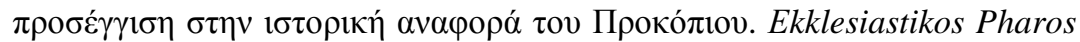
92 (New Series 21): 305-343. 